\title{
PENDIDIKAN KESEHATAN DENGAN METODE BRAINSTORMING DAN MEDIA AUDIOVISUAL BERPENGARUH TERHADAP PENGETAHUAN IBU TENTANG PENCEGAHAN DIFTERI
}

\author{
Filly Fikriyati Azki ${ }^{1}$, Rokhaidah ${ }^{2}$ \\ 1,2Fakultas Ilmu Kesehatan Universitas Pembangunan Nasional Veteran Jakarta \\ Email : rokhaidah@upnvj.ac.id
}

\begin{abstract}
ABSTRAK
Latar belakang : Difteri berakibat fatal pada 5-10\% kasus, dengan angka kematian yang lebih tinggi pada anak-anak. Salah satu pencegahan difteri yaitu dengan upaya promotif melalui pendidikan kesehatan. Metode brainstorming dan media audiovisual dapat digunakan dalam pendidikan kesehatan agar lebih efektif. Tujuan penelitian ini adalah untuk menganalisis pengaruh pendidikan kesehatan menggunakan metode brainstorming dan media audiovisual terhadap pengetahuan Ibu balita tentang pencegahan difteri. Metode penelitian ini yaitu kuasi eksperimen dengan. Penelitian ini menggunakan uji wilcoxon dengan convident interval 95\%. Hasil analisis statistik didapatkan p value $<0,05$ yang berarti terdapat perbedaan pengetahuan Ibu sebelum dan setelah dilakukan intervensi. Pengetahuan ibu tentang difteri meningkat setelah dilakukan intervensi Kesimpuan : Pendidikan kesehatan menggunakan metode brainstorming dan media audiovisual dapat meningkatkan pengetahuan ibu tentang difteri. Rekomendasi : Penggunaan metode brainstroming dengan media audiovisual untuk pendidikan kesehatan sebagai upaya preventif dan promotif untuk penyakit difteri.
\end{abstract}

Kata kunci : Audiovisual, Brainstorming, Difteri, Pengetahuan, Ibu

\begin{abstract}
Diphtheria is fatal in 5-10\% of cases, with a higher mortality rate in children. One of the diphtheria debates is with promotive efforts through health education. Brainstorming methods and audiovisual media can be used in health education to be more effective. The purpose of this study was to analyze education using brainstorming methods and audiovisual media on the knowledge of toddlers about opposing diphtheria. This research method is a quasi experiment with. This research uses Wilcoxon test with 95\% clear interval. Statistical analysis results obtained $p$ value $<0.05$ which means differences in knowledge of the mother before and after the intervention. Maternal knowledge about diphtheria increases after intervention Conclusion: Health education using brainstorming methods and audiovisual media can increase mothers' knowledge of diphtheria. Recommendation: the use of brainstorming methods with audiovisual media for health education as a preventive and promotive effort for diphtheria.
\end{abstract}

Keywords : Audiovisual, Brainstorming, Diphteria, Knowledge, Mother.

Alamat Korespondensi: Fakultas Ilmu Kesehatan UPN Veteran Jakarta

Email: rokhaidah@upnvj.ac.id 


\section{PENDAHULUAN}

Difteri merupakan penyakit infeksi akut yang dapat menular melalui percikan ludah atau droplet dari orang yang terinfeksi. Penyakit ini disebabkan oleh Corynebacterium diphtheria yaitu suatu bakteri gram positif fakultatif anaerob, bakteri ini dapat bertahan hidup di udara luar hingga 6 bulan. Difteri pada umunya ditandai dengan gejala seperti nyeri saat menelan, demam, malaise, dan sakit tenggorokkan. Pada pemeriksaan laboratorium (swab tengorok, kultur) menunjukkan pseudomembran tampak berwarna putih keabuan dan dapat menyebabkan penyumbatan sehingga terjadi penyempitan saluran napas dan mengakibatkan sulit untuk bernapas hingga kematian. Difteri biasanya diikuti dengan komplikasi seperti obstruksi jalan napas, miokarditis, paralisis otot palatum, otitis media dan juga dapat menyebar ke paru-paru hingga dapat menyebabkan pneumonia (Hartoyo, 2018).

Difteri berakibat fatal pada 5-10\% kasus, dengan angka kematian pada anak-anak lebih tinggi. Jika terjadi keterlambatan dalam mendiagnosis atau tidak terdeteksi maka akan menyebabkan pula keterlambatan dalam menangani gejala tersebut sehingga dapat menimbulkan komplikasi klinik yang fatal hingga berujung kematian (Arifin and Prasasti, 2018).

Tahun 2013 jumlah kasus Difteri di Indonesia tercatat ada 775 kasus, dan pada tahun 2014 mengalami penurunan menjadi 430 kasus. Pada tahun 2015 kasus difteri di Indonesia tercatat ada 529 kasus dan pada tahun 2016 mengalami sedikit peningkatan menjadi 591 kasus. Hasil tersebut sebanding dengan jumlah kabupaten/kota. Pada tahun 2015 tercatat ada 89 kabupaten/kota dan pada tahun 2016 meningkat menjadi 100 kabupaten/kota (Kemenkes, 2017). Pada tahun 2017 data dari kementerian kesehatan terdapat 954 kasus difteri di 170 kabupaten/kota di 30 provinsi dan 44 orang diantaranya meninggal dunia. Hingga Januari 2018 ada 14 kasus terlapor dari 11 kabupaten/kota di 4 provinsi yaitu provinsi DKI Jakarta, Banten, Jawa Barat dan Lampung (Kementerian Kesehatan Republik Indonesia, 2018).

Jawa Barat sendiri khususnya Kota depok pada tahun 2016 tercatat ada 8 kasus difteri, dan pada tahun 2017 tercatat ada 4 kasus difteri dan 8 lainnya dinyatakan statusnya masih suspek. Pada tahun 2017 terdapat 1 anak meninggal dunia karena difteri. Dari data yang didapatkan ada 1 anak positif terkena difteri di Kelurahan Limo Kota Depok. Hasil studi pendahuluan di kelurahan Limo Depok mendapatkan hasil bahwa dari 10 ibu yang memiliki anak, 8 diantaranya tidak mengetahui tanda gejala, cara penularan dan cara pencegahan difteri. Ada 2 ibu yang mengetahui tanda gejala tapi tidak mengetahui cara penularan dan cara pencegahan difteri.

Tingkat pengetahuan orang tua juga berpengaruh terhadap angka kejadian difteri. Tingkat pengetahuan yang rendah akan mempengaruhi sikap dan tindakan orang tua dalam mencegah difteri. Dari hasil penelitian yang dilakukan oleh Afifaturochmah dkk (2014) tentang preventive service dan preventive health education berdasarkan tannahill's model meningkatkan perilaku ibu dalam pencegahan difteri pada anak menyatakan bahwa adanya peningkatan pada pengetahuan, sikap dan tindakan ibu dalam mencegah difteri setelah dilakukan intervensi. Pengetahuan seseorang dapat ditingkatkan melalui pendidikan kesehatan. Dengan pendidikan kesehatan seseorang dapat memperoleh informasi dan menambah pengetahuan tentang apa yang disampaikan oleh penyaji (Hardita, Qur'aniati and Kristiawati, 2014).

Salah satu metode pendidikan kesehatan yaitu menggunakan metode brainstorming, metode ini melibatkan seluruh audiens untuk mengutarakan pendapat, ide, pengetahuan dan pengalamannya untuk memecahkan sebuah masalah yang sudah ditentukan sebelumnya. Hasil dari pendapat, ide, pengetahuan, dan pengalaman audiens dikumpulkan menjadi satu dan dibuat mindmap (peta informasi) untuk menjadi pembelajaran bersama (Hardita, Qur'aniati and Kristiawati, 2014). Media yang dapat digunakan dalam pendidikan 
kesehatan yaitu dengan menggunakan media audiovisual. Media audio visual dapat membantu peserta menstimulasi indra pendengaran dan penglihatan saat proses pendidikan kesehatan (Lumbanbatu, 2018).

\section{METODE PENELITIAN}

Desain penelitian yang digunakan yaitu quasi eksperimen dengan satu kelompok pretest-posttest. Instrumen yang digunakan pada penelitian ini yaitu kuesioner pengetahuan yang berjumlah 19 pertanyaan dengan menggunakan skala guttman. Pengisian kuesioner dilakukan sebelum dan sesudah dilakukan pendidikan kesehatan. Waktu pengambilan data dilakukan pada bulan Mei 2019 di Kelurahan Limo Depok Jawa Barat. Populasi Ibu pada penelitian ini sebanyak 421 yang berada di wilayah RW 01, 02 dan 03 kelurahan Limo. Sampel pada penelitian ini berjumlah 42 responden dengan menggunakan rumus yang ketentuannya ditetapkan dari penelitian sebelumnya. Teknik pengambilan sampel menggunakan purposive sampling.

Variabel dependen pada penelitian ini adalah pengetahuan Ibu balita tentang pencegahan difteri. Sedangkan variabel independennya yaitu pendidikan kesehatan menggunakan metode brainstorming dan media audiovisual tentang pencegahan difteri.

Responden mengisi kuesioner pretst terebih dahulu, kemudian setelah sumua responden sudah mengumpulkan kuesionernya baru dilakukan pendidikan kesehatan. Pendidikan kesehatan yang pertama dimulai dengan pemutaran vidio yang berduari kurang lebih 7 menit selama satu kali. Kemudian setelah itu responden dibagi menjadi kelompok-kelompok kecil untuk melakukan brainstorming. Pada pemberian edukasi menggunakan metode brainstorming, peneliti memberi suatu masalah yaitu mengenai difteri. Kemudian setiap responden mengutarakan pendapat, pengalaman dan pengetahuan yang dimilikinya.

Analisis univariat dilakukan untuk mengetahui karakteristik ibu balita dan juga variabel pengetahuan Ibu pretest dan posttest. Hasil uji normalitas diketahui variabel pengetahuan Ibu pretest dan posttest tidak terdistribusi normal, sehingga uji selanjutnya menggunakan uji wilcoxon dengan tingkat kepercayaan 95\% untuk mengetahui adanya perbedaan pengetahuan Ibu balita tentang pencegahan difteri saat pretest dan posttest.

Hasil uji normalitas pada penelitian ini data terdistribusi tidak normal. Peneliti sudah melakukan usaha untuk menormalkan data dengan menggunakan uji log 10, uji ln, dan uji SQRT Maka penelitian ini menggunakan uji wilcoxon karena distribusi sampelnya tidak normal.

\section{HASIL}

\section{Karakteristik Responden}

Tabel 1. Karakteristik responden

\begin{tabular}{lcc}
\hline \multicolumn{1}{c}{ Variabel } & Frekuensi & $\begin{array}{c}\text { Prosentase } \\
(\mathbf{\%})\end{array}$ \\
\hline $\begin{array}{l}\text { Pendidikan } \\
\text { Formal } \\
\text { Terakhir }\end{array}$ & & \\
\hline SD, SMP & 18 & 42,9 \\
\hline $\begin{array}{c}\text { SMA, } \\
\text { Perguruan } \\
\text { tinggi }\end{array}$ & 24 & 57,1 \\
\hline Pekerjaan & & \\
\hline Tidak Bekerja & 39 & 92,9 \\
\hline \multicolumn{1}{c}{ Bekerja } & 3 & 7,1 \\
\hline
\end{tabular}


Responden pada penelitian ini berjumlah 42 Ibu yang memiliki balita di RW 01, 02 da 03 Kelurahan Limo. Sebagian besar responden berpendidikan tingi (SMA, Perguruan Tinggi). Sebagian besar responden tidak bekerja, hanya menjadi ibu rumah tangga.

Penelitian Husni dan Suheti (2017) mengemukakan bahwa tingkat pendidikan seseorang mempunyai peran andil dalam menentukan mudah atau tidaknya memahami dan menyerap suatu pengetahuan atau informasi yang diperolehnya. Pada umumnya semakin tinggi pendidikan seseorang maka semakin tinggi pula pengetahuannya (Husni and Suheti, 2017). Pada umunya seseorang yang memiliki pendidikan rendah akan lebih sulit untuk menyerap ide-ide atau informasi yang diberikan dan lebih bersifat konservatif. Sebaliknya seseorang yang memiliki latar beakang berpendidikan tinggi pada umumnya lebih terbuka dan lebih mudah menerima ide-ide baru atau informasi yang diberikan (Novrianda and Yeni, 2014).

Ibu yang bekerja dan tidak bekerja mempunyai peluang yang sama untuk memiliki pengetahuan yang baik. Ibu yang tidak bekerja akan lebih banyak memiliki waktu untuk mencari informasi tentang keshatan anak dan juga dapat lebih memperhatikan kesehatan anaknya. Sedangkan Ibu yang bekerja juga dapat memperoleh informasi dengan menjalin hubungan dengan rekan kerja sehingga dapat menambah pengetahuan dan wawasan dengan sudut pandang yang beragam (Novrianda and Yeni, 2014).

Tabel 2 Karakteristik Usia Responden

\begin{tabular}{ccccc}
\hline Variabel & Mean & $\begin{array}{c}\text { Standar } \\
\text { Deviasi }\end{array}$ & $\begin{array}{c}\text { Minimum } \\
\text { (tahun) }\end{array}$ & $\begin{array}{c}\text { Maksimum } \\
\text { (tahun) }\end{array}$ \\
\hline Usia & 31,81 & 6,918 & 19 & 46 \\
\hline
\end{tabular}

Distribusi frekuensi usia responden pada penelitian ini memiliki rentang usia antara 19 sampai 46 tahun. Usia merupakan suatu faktor yang dimiliki oleh setiap individu dimana saat usia seseorang bertambah maka akan semakin dewasa serta bertambah pula pengalamannya sehingga semakin banyak informasi yang diperoleh. Lebih lama hidupnya maka lebih banyak pula pengalaman dan informasi yang diperoleh sehingga pengetahuan yang dimilikinya juga bertambah (Novrianda and Yeni, 2014).

Rentang usia 36-45 tahun merupakan usia yang matang, dimana pada usia tersebut seseorang memiliki daya tangkap dan pola pikir yang baik sehingga pengetahuan yang dimiliki juga baik (Wardani, SR and Masfiah, 2014). Penelitian yang dilakukan oleh Qiyam dkk (2016) menyatakan bahwa terdapat hubungan antara umur dengan pengetahuan tentang ISPA. Pada usia 20-30 tahun merupakan usia yang dapat dikatakan daya kemampuan secara fisik dan psikologisnya baik sehingga mampu dalam menghadapi kejadian ISPA pada anaknya serta dapat menangani dengan melakukan perawatan yang tepat sesuai dengan pengetahuan yang dimilikinya (Fauziningtyas, Mia and Makhfudli, 2018).

\section{Pengetahuan Responden}

Pengetahuan Ibu diukur menggunakan kuesioner pengetahauan yang berjumlah 19 soal yang terdiri dari 6 domain mencakup. Kuesioner trsebut menggunakan skala guttman.

Tabel 3. Skor Pretest dan Posttest Pengetahuan Responden tentang Penceghan Difteri

\begin{tabular}{lcccc}
\hline Variabel & Mean & $\begin{array}{l}\text { Standar } \\
\text { Deviaasi }\end{array}$ & $\begin{array}{l}\text { Skor } \\
\text { Terendah }\end{array}$ & $\begin{array}{l}\text { Skor } \\
\text { Tertingi }\end{array}$ \\
\hline Pretest & 15,76 & 2,261 & 10 & 18 \\
\hline Posttest & 18,00 & 1,448 & 13 & 19 \\
\hline
\end{tabular}


Hasil pengetahuan responden sebelum dilakukan intervensi menunjukkan skor terendah 10 (benar 10 dari 19 pertanyaan) skor tertinggi 18 (salah 1). Skor 10 berarti responden memiliki pengetahuan kurang tentang pencegahan difteri, sedangkan skor 18 memiliki arti responden memiliki pengetahuan baik tentang pencegahan difteri. Hasil pengetahuan responden setelah mengikuti kegiatan pendidikan kesehatan tentang pencegahan difteri menunjukkan bahwa skor terendah 13 (salah 6 dari 19 pertanyaan) dan skor tertinggi 19 (benar semua). Skor 13 berarti responden memiliki pengetahuan cukup tentang pencegahan difteri, sedangkan skor 19 memiliki arti responden memiliki pengetahuan baik tentang pencegahan difteri.

Tabel 4. Hasil Uji Beda Antara Skor Pretest dan Posttest pada Variabel Pengetahuan Ibu

\begin{tabular}{lllc}
\hline Intervensi & Mean & SD & P Value \\
\hline Pretest & 15,76 & 2,261 & 0,000 \\
\cline { 1 - 3 } Postest & 18,00 & 1,448 &
\end{tabular}

Hasil yang diperoleh dari uji wilcoxon dengan nilai a $(0,05)$ yaitu $p$ value $=0,000$ yang memiliki arti bahwa terdapat perbedaan yang signifikan antara pengetahuan ibu balita sebelum dan sesudah dilakukan pendidikan kesehatan menggunakan metode brainstorming dan media audiovisual. Terjadi peningkatan pada rata-rata pengetahuan ibu dari 15,77 menjadi 17,95

\section{PEMBAHASAN}

Hasil penelitian ini sejalan dengan penelitian sebelumnya yang menyatakan bahwa pemberian pendidikan kesehatan dengan menggunakan metode brinstorming dan audiovisual dapat meningkatkan pengetahuan ibu tentang stunting di Desa Gununglurah, Kecamatan Cilongkok, Kabupaten Banyumas (Aqmarina et al., 2019).

Edukasi dengan menggunakan metode brainstorming memiliki kelebihan yaitu semua anggota dapat mencurahkan pendapatnya dan merangsang anggotanya untuk berpikir kritis serta turut andil dalam pendidikan kesehatan (Syafi udin, Wantiyah and Kushariyadi, 2018). Pada metode ini responden mendapatkan informasi melalui diskusi kelompok, semua responden berhak mencurahkan pendapatnya tanpa adanya sanggahan dari siapapun. Metode ini juga dapat memicu responden untuk berpikir aktif dan saling berbagi satu sama lain, sehingga timbul komunikasi antar responden dan dapat menciptakan suasana yang menyenangkan (Fauziningtyas, Mia and Makhfudli, 2018).

Metode Brainstorming dapat meningkatkan daya ingat dan melatih peserta agar terlatih berpikir dan meningkatkan konsentrasi, perhatian dan pemahaman. Metode ini juga dapat meningkatkan percaya diri peserta saat menampaikan pendapatnya, karena menyampaikan pendapat atau berbicara di depan orang banyak membutuhkan keberanian (Hardita, Qur'aniati and Kristiawati, 2014).

Salah satu media yang dapat digunakan untuk edukasi yaitu media audio visual. Media audiovisual dapat membantu peserta menstimulasi indra pendengaran dan penglihatan saat proses pendidikan kesehatan (Lumbanbatu, 2018). Menggunakan media audiovisual dapat memudahkan peserta dalam menerima materi yang disampaikan, karena dapat mengaktifkan indra pendengaran dan indra penglihatan peserta sehingga dapat menghubungkan teori dengan realita (Fujiyanto, Jayadinata and Kurnia, 2016). Menggunakan media audiovisual dalam bentuk vidio mempunyai kelebihan yaitu dapat menggambarkan kadaan sesuai dengan realita yang ada, kemudian vidio juga bersifat dinamis sehingga dapat memberi kesan dan merangsang emosi peserta (Syafi udin, Wantiyah and Kushariyadi, 2018). 
Hasil penelitian ini sejalan dengan penelitian sebelumnya yang menyatakan bahwa pemberian pendidikan kesehatan dengan menggunakan metode brinstorming dan audiovisual dapat meningkatkan pengetahuan ibu tentang stunting di Desa Gununglurah, Kecamatan Cilongkok, Kabupaten Banyumas (Aqmarina et al., 2019).

\section{KESIMPULAN DAN SARAN}

Pemberian pendidikan kesehatan menggunakan metode brainstorming dan media audiovisual dapat meningkatkan pengetahuan Ibu tentang pencegahan difteri di Kelurahan Limo Depok Jawa Barat. Penelitian selanjutnya perlu dikembangkan dengan adanya monitoring dan evaluasi pada jangka waktu tertentu untuk melihat kemampuan daya ingat Ibu serta sikap Ibu terhadap pencegahan difteri.

Saran untuk profesi keperawatan komunitas yaitu untuk memberikan intervensi khususnya dalam memberikan penyuluhan kesehatan tentang pencegahan difteri menggunakan metode brainstorming dan media audiovisual serta melakukan monitoring terhadap pengetahuan dan sikap ibu terhadap penyakit difteri setelah dilakukan intervensi.

\section{DAFTAR PUSTAKA}

Aqmarina, A. N. et al. (2019) 'Pengaruh Edukasi Stunting Menggunakan Metode Brainstorming dan Audiovisual Terhadap Pengetahuan Ibu dengan Anak Stunting', 02(02), pp. 141-146.

Arifin, I. F. and Prasasti, C. I. (2018) 'Factors That Related With Diptheria Cases of Children in Bangkalan Health Centers', Jurnal Berkala Epidemiologi, 5(1), p. 26. doi: 10.20473/jbe.v5i12017.26-36.

Fauziningtyas, R., Mia, A. Y. D. and Makhfudli (2018) ‘Efek Metode Brainstorming Terhadap Tingkat Pengetahuan dan Rasionalitas Penggunaan Obat Swamedikas', 6(1), pp. 5566.

Fujiyanto, A., Jayadinata, A. K. and Kurnia, D. (2016) 'Penggunaan Media Audio Visual untuk Meningkatkan Hasil Belajar Siswa pada Materi Hubungan Antarmakhluk Hidup', Jurnal Pena Ilmiah, 1(1).

Hardita, D. M., Qur'aniati, N. and Kristiawati (2014) 'Brainstorming Dalam Pencegahan Infeksi Saluran Pernapasan Akut (ISPA) Oleh Ibu'. Hartoyo, E. (2018) 'Difteri Pada Anak', Sari Pediatri, 19(5), p. 300. doi: 10.14238/sp19.5.2018.300-6.

Husni, A. and Suheti, T. (2017) 'Pengaruh Penerapan Metode Pembelajaran Brainstorming Terhadap Peningkatan Pengetahuan Tentang Osteoporosis Pada Pra Lansia Di Posbindu Kelurahan Pajajaran Kota Bandung', 12.

Kemenkes (2017) 'Pedoman Pencegahan dan Pengendalian Difteri'.

Kementerian Kesehatan Republik Indonesia (2018) 'Pemerintah Optimis KLB Difteri Bisa Teratasi', Www.Depkes.Go.Id, pp. 1-3. doi: 10.1016/B978-0-444-62630-1.00001-9.

Lumbanbatu, A. M. R. (2018) 'Efektifitas Audio Visual Sebagai Media Pendidikan Kesehatan Terhadap Pengetahuan Keluarga Pasien Penyakit Ginjal Kronik Di Unit Hemodialisis Rumah', 5(Dm).

Novrianda, D. and Yeni, F. (2014) 'Hubungan Karakteristik Ibu dengan Pengetahuan tentang Penatalaksanaan Diare pada Balita', 10(1), pp. 159-166.

Syafi'udin, M., Wantiyah, W. and Kushariyadi, K. (2018) 'Pengaruh Pendidikan Kesehatan Metode Brainstorming dan Video terhadap Pengetahuan tentang Demam Berdarah pada Keluarga di Wilayah Kerja Puskesmas Puger Kabupaten Jember', Pustaka Kesehatan, 6(1), p. 141. doi: 10.19184/pk.v6i1.6869.

Wardani, N. I., SR, D. S. and Masfiah, S. (2014) 'Faktor-Fakto yang Berhubungan dengan Tingkat Pengetahuan Kader Kesehatan Tentang Thalasemia di Kecamatan Sumbang Kabupaten Banyumas', pp. 194-207. 